\title{
Conflicto entre las libertades de expresión e información y el derecho al honor, la intimidad y la propia imagen del menor*
}

\author{
Alba Paños Pérez**
}

\begin{abstract}
RESUMEN
El trabajo analiza la colisión entre las libertades fundamentales de información y expresión y los derechos al honor, la intimidad y la propia imagen de los menores cuando estos son acusados de delito. Se postula que la habitual aparición de imágenes sobre menores involucrados en delitos en los distintos medios audiovisuales en España es algo probibido expresamente por el ordenamiento jurídico de ese país.
\end{abstract}

Menores de edad - derecho al honor - publicidad procesal

\section{Conflict between freedoms of expression and information and the right of honour, privacy and self-image of minors}

\section{Abstract}

This paper analyses the conflict between fundamental freedoms of information and expression and the right to honour, privacy and self-image of minors accused of a crime. It is stated that the frequent publication of images of minors involved in crimes across various media in Spain is expressly forbidden by the law of that country.

Minors - right to honour - publicity and legal proceedings

* Este trabajo se enmarca dentro del Proyecto de Investigación TIC-6237 "Protección integral de los menores en el ámbito audiovisual".

** Doctora en derecho, Profesora ayudante de Derecho Civil, Facultad de Derecho, Universidad de Almería, Edificio D, Despacho 2.27. Ctra. Sacramento, s/n. La Cañada de San Urbano; 04120- Almería, España.Correo electrónico: albapanos@ual.es

Artículo recibido el 16 de agosto de 2012 y aceptado para su publicación por el Comité Editorial en 26 de octubre de 2012. 


\section{El PRINCIPIO DEL INTERÉS DEL MENOR}

\subsection{Una aproximación conceptual}

$\mathrm{E}$ 1 interés del menor, que equivale en este contexto a la expresión interés superior del menor $^{1}$, se presenta actualmente como directriz básica que impregna el Derecho moderno de menores.

Partiendo de la dificultad que entraña siquiera el intento de definición de un principio de naturaleza tan genérica y con una puesta en práctica caracterizada por el relativismo, vamos a aproximarnos a su delimitación de la mano de algunas de las opiniones doctrinales dadas al respecto.

Rivero Hernández ${ }^{2}$, tras dejar constancia de la problemática que supone aportar ideas con alguna validez como concepto o categoría general respecto de este término ${ }^{3}$, señala que el interés del menor informa nuestro ordenamiento jurídico con la amplitud y energía de un principio general de Derecho, está presente en muchas normas concretas y es preciso tratar de conocerlo, a falta de definición precisa, hasta donde nos sea posible.

Así pues, el interés del menor, además de principio general de Derecho privado, constituye per se un principio constitucional (derivado del art. $39 \mathrm{CE}$, con relación al art. 10.1 CE), uno de los principios rectores amparados por nuestra Constitución (arts. 39 a $52 \mathrm{CE}$ ), la cual le otorga la superioridad normativa formal que ella misma implica. En efecto, en esa calidad de principio general, reforzado por su elevación a constitucional, además de ser garantía para los ciudadanos y vincular a los poderes públicos, el interés del menor actúa como instrumento informador de instituciones que afectan a las personas que se pretende proteger, proporciona criterios de interpretación y, además, deviene norma supletoria de aplicación cuando proceda a falta de otra norma especial.

A mayor abundamiento, el interés del menor como standard jurídico ${ }^{4}$ constituye un concepto jurídico indeterminado por medio del cual la ley se refiere a una realidad cuyos límites no precisa con exactitud, con lo que intenta definir o delimitar un supuesto

\footnotetext{
${ }^{1}$ Según Rivero Hernández la presencia o ausencia del adjetivo "superior” no altera su alcance jurídico; con este adjetivo se pretende destacar la prioridad del interés del menor sobre otros, su superioridad en caso de conflicto con otros intereses. El interés del menor, $2^{\mathrm{a}}$ Ed., Dykinson, Madrid, 2007, pp. 74-75.

${ }^{2}$ Vid. El interés del menor...cit., pp. 62-64, 81-85.

${ }^{3}$ Otros autores que han criticado el alto grado de abstracción y vaguedad de este término, a modo de ejemplo: Gullón Ballesteros, A., "Sobre la Ley 1/1996, de Protección Jurídica del Menor”, en @La Ley, D-40, 1996; Alonso Pérez, M. "La situación jurídica del menor en la Ley Orgánica 1/1996, de 15 de enero, de protección jurídica del menor, de modificación del Código Civil y de la Ley de Enjuiciamiento Civil: luces y sombras", en Actualidad Civil, No 2, 1997, pp. 23 y ss; Navas Navarro, S., "El bienestar y el interés del menor desde una perspectiva comparada", en Estudios Jurídicos en Homenaje al Profesor Luis Diez-Picazo, T. I, Madrid, 2003, p. 707.

${ }^{4}$ Así lo define Rivero Hernández, como standard jurídico: un modelo de conducta o actuación jurídicosocial que se adecua a lo que demanda la conciencia social de acuerdo con unos principios y sensibilidad sociales, distinguido, frente a otros, por la realidad vital a la que va referido (lo que se busca es lo mejor para un niño o un joven, no un abstracto interés) y caracterizado por su relativismo y su aspecto dinámico; Vid. El interés del menor...cit., pp. 67-71.
} 
concreto que permite que sea precisado después, en el momento de su aplicación. Es decir, se ha recurrido a la utilización de un concepto llamado de valor o de experiencia, referido a una realidad que inicialmente no permite una mayor precisión, pero que, trasladada a unas situaciones específicas o unos supuestos determinados, su aplicación conduce a una solución y no otras.

Hay autores que defienden que este concepto jurídico es indeterminado pero solo relativamente ${ }^{5}$. Además, esta indeterminación tendría sus ventajas, a saber, que permite ponderar el interés del menor teniendo en cuenta las circunstancias que concurren en cada supuesto concreto, así como su propia individualidad y adoptar la solución que le sea más beneficiosa; y también sus inconvenientes, como el excesivo condicionamiento de la resolución del problema planteado, o de la medida a adoptar, a criterios subjetivos de los responsables de su interpretación y aplicación.

Otros autores denuncian sin tapujos que no nos encontramos ante un concepto jurídico relativamente indeterminado, sino absolutamente indeterminado en cuanto a su contenido, además de fácilmente manipulable según los intereses que estén en juego en un supuesto concreto. Y ello porque se encuentra situado en la cúspide de la pirámide que representa la jerarquía de intereses que convergen en el ámbito de la protección del menor y la tutela de sus derechos ${ }^{6}$.

Así pues, lo más conveniente y adecuado al interés superior del menor no podría establecerse con precisión sino con referencia a las circunstancias de hecho que nos encontremos cada vez que sea necesaria la determinación de dicho interés. No obstante, para evitar que este modus operandi generase una gran inseguridad jurídica habría que alcanzar previamente un acuerdo acerca de la utilización de un criterio de interpretación del citado principio que nos permita una aplicación coherente y homogénea del mismo.

En este sentido, Rivero Hernández ${ }^{7}$ establece que, en una primera aproximación, el interés del menor se nos presenta y refiere a una ventaja efectiva para el niño o adolescente (componente positivo), conjugada en ocasiones con la evitación de perjuicio o previsible desventaja para él (componente negativo). Así, el interés del menor comprendería tanto los bienes materiales y patrimoniales como los espirituales o ideales; en suma, todos aquellos que la persona considera (subjetivamente) valiosos.

De otro lado, Alonso Pérez ${ }^{8}$, en una acepción más precisa y tras hacerse eco igualmente de la incertidumbre que desprende este concepto indeterminado y genérico (“criterio básico y preferente" en los procedimientos de familia), señala que el interés superior del menor debe referirse al desenvolvimiento libre e integral de su personalidad,

${ }^{5}$ Vid. Camps Mirabet, N., "El principio del interés superior del menor: marco normativo internacional y aplicación en el derecho interno”, en Estudios jurídicos sobre la protección de la infancia y de la adolescencia, Tirant lo blanch, Valencia, 2007, pp. 24-25; quien señala que en virtud del principio del interés superior del menor prevalecerá la consideración primordial de los derechos del niño frente a cualquier otro interés en presencia.

6 Jiménez-Aybar, I., "Diálogo sobre el principio del interés superior del menor", en La familia, protagonista, Comisión Organizadora del Congreso General de Familia, 2003, p. 487.

${ }^{7}$ El interés del menor...cit., p. 66.

${ }^{8}$ Vid. "La situación jurídica del menor...cit., p. 24. 
a la supremacía de todo lo que le beneficie más allá de las apetencias personales de sus padres, tutores, curadores o administraciones públicas, en orden a su desarrollo físico, ético y cultural. La salud corporal y mental, su perfeccionamiento educativo, el sentido de la convivencia, la tolerancia y la solidaridad con los demás sin discriminación de sexo, raza, etc., la tutela frente a las situaciones que degradan la dignidad humana, son otros aspectos que configurarían el concepto más vivencial que racional del interés del menor. Pero, por encima de todo, el interés del menor se respeta en la medida en que las funciones familiares o parafamiliares fomentan equilibradamente la libertad del menor y el sentido de la responsabilidad, la armonía inexcindible entre derecho y deber.

Por su parte, De Lama Aymá ${ }^{9}$ defiende que es un error creer que no hay reglas preferibles a otras o que no puede establecerse un contenido mínimo del concepto de interés del menor. Se ha afirmado que el contenido esencial del interés del menor consiste básicamente en proteger y garantizar sus derechos fundamentales como persona y fomentar el libre desarrollo de su personalidad; proyectándose, por tanto, sobre los derechos y valores reconocidos en el artículo 10.1 CE, es decir, la dignidad y el libre desarrollo de la personalidad del individuo así como sus derechos fundamentales ${ }^{10}$. Pues bien, esta autora delimita el contenido del principio como la salvaguarda de los bienes jurídicos de la personalidad, bien mediante la figura del derecho subjetivo permitiendo que el menor actúe por sí mismo cuando tenga madurez suficiente, bien por medio del cumplimiento de la función social inherente en la patria potestad y el respeto al interés legítimo en la protección de la persona del menor de edad.

No obstante, algún autor defiende finalmente que solo la casuística puede perfilar este concepto jurídico indeterminado ${ }^{11}$. Rivero Hernández ${ }^{12}$, sin embargo, propone dos caminos a seguir, paralelos y complementarios: por un lado, opina que debemos abordar la cuestión de la determinación del interés del menor en un plano inicialmente genérico y un tanto teórico; y por otro, plantea estudiar cómo se determina el interés del menor en áreas jurídicas específicas y referidas a situaciones y casos vividos en la realidad diaria. Precisamente esto último es lo que nos proponemos en este trabajo, la delimitación del interés del menor como límite y como criterio de ponderación en las intromisiones en el honor, la intimidad y la propia imagen de los menores de edad. Aportando, en última instancia y a modo de conclusión, la reflexión sobre un caso concreto que ha suscitado gran polémica en la sociedad actual.

${ }^{9}$ Vid. La protección de los derechos de la personalidad del menor de edad, Tirant lo Blanch, Valencia, 2006, pp. $95-97$.

${ }^{10}$ En este sentido, Navas Navarro, S., define el interés del menor como la voluntad del legislador de garantizar ante situaciones que puedan perjudicar al menor o poner en peligro su bienestar, el óptimo desarrollo de su personalidad mediante el ejercicio de sus derechos fundamentales. Vid. "El bienestar y el interés del menor...cit., pp. 693 y 707.

${ }^{11}$ Linacero de la Fuente, M., "La protección del menor en el Derecho civil español. Comentario a la Ley 1/1996, de 15 de enero", en Actualidad Civil, La Ley, 1999, pp. 1573 y ss.

${ }^{12}$ Vid. El interés del menor...cit., pp. 101 y ss. 


\subsection{El interés del menor como límite infranqueable}

El artículo 20.4 de la Constitución española dice que las libertades de información y expresión "tienen su límite en el respeto a los derechos reconocidos en este Título, en los preceptos de las leyes que lo desarrollen y, especialmente, en el derecho al honor, a la intimidad, a la propia imagen y a la protección de la juventud y de la infancia”. Entendemos que esta última alusión a la protección de la juventud y de la infancia hace referencia a la tutela y garantía del interés del menor, es decir, al respeto, protección y fomento de los derechos fundamentales del menor.

Esta confrontación del derecho a la libertad informativa y la protección de la juventud y la infancia está claramente regulada, además, en el artículo 39.2 CE, donde se ordena a los poderes públicos otorgar la máxima protección al menor y en el artículo 25 de la Declaración Universal de los Derechos Humanos, que protege la infancia y la maternidad.

Tanto la jurisprudencia como la doctrina son claramente favorables a la libertad de expresión en caso de confrontación de estos derechos en personas mayores de edad, si bien ofrecen una mayor preeminencia al derecho a la intimidad de los menores de edad, en orden a proteger ese interés superior de los mismos ${ }^{13}$. Por tanto, el ejercicio de las libertades de información y expresión deberá respetar los derechos del menor, lo cual, en la medida en que este está formando su personalidad todavía, supone un mayor grado de prudencia por parte de los medios de comunicación que con relación a los mayores de edad.

Así pues, el fundamento de esta protección del menor se centra en la falta de desarrollo físico y psíquico de este, lo que comporta que asuma menos fácilmente que un adulto las consecuencias de las posibles intromisiones de los medios de comunicación en su honor, intimidad e imagen. De ahí que el tratamiento de las informaciones relativas a los menores deba realizarse bajo un prisma de mayor garantía de los derechos fundamentales y de interpretación restrictiva del ejercicio de la libertad de información y expresión ${ }^{14}$. Además, el tratamiento informativo del menor debe inspirarse en el principio general de protección reforzada de sus derechos a la intimidad y a la propia imagen.

Sin embargo, no debemos olvidar que es necesario buscar un equilibrio entre esta protección a los menores y el derecho a recibir información que tienen todos los ciudadanos por aplicación estricta del derecho a las libertades de expresión e información

${ }^{13}$ Un claro ejemplo de ponderación entre la libertad de información y los derechos al honor y la intimidad de un menor, en la que no se aprecia intromisión ilegítima en los mismos: STS de 8 de septiembre de 2009 (RJ 2009/6490), respecto de la noticia publicada en un periódico sobre un menor delincuente en la zona del Albaicín, Granada.

${ }^{14}$ No obstante, De Lama Aymá, A., La protección de los derechos... cit., pp. 255-256 y 263, señala que existe una tendencia a negar cualquier causa de legitimación de las intromisiones en el honor del menor y, en consecuencia, hay un acercamiento a la responsabilidad objetiva de quien difunde una información que supone una intromisión ilegítima en el honor del menor, puesto que se exigiría un mayor grado de diligencia que en informaciones relativas a adultos, pues la diligencia no alcanza solo a la veracidad de la información sino también a la no identificación del menor. 
así como a la libertad de prensa. Libertad de prensa que, con su indudable valor en una sociedad democrática, quedará supeditada a la protección de la infancia, tal y como se deriva de la normativa aplicable y de la jurisprudencia del Tribunal Constitucional.

Pues bien, del análisis jurisprudencial se desprende que los criterios de ponderación genéricos para determinar cuándo la intromisión en el honor, la intimidad y la imagen es legítima, es decir, cuándo la libertad de información prima sobre estos derechos, son los siguientes ${ }^{15}$ : que lo difundido tenga interés público ${ }^{16}$, que sea veraz ${ }^{17}$ y que no sea gratuito, es decir, que la información contribuya a formar la opinión pública ${ }^{18}$.

$\mathrm{Al}$ respecto, es necesario precisar qué se entiende por interés general o por relevancia pública. El interés informativo nunca debe estar vinculado a razones subjetivas, es decir, cuando se trate de abordar la intimidad de los menores no se puede vincular a los gustos del público (interés general que no informativo), pues entonces ese interés informativo estaría basado en razones meramente subjetivas, pero ajenas a la subjetividad del menor. Por el contrario, el interés informativo deberá estar vinculado a razones objetivas, en función del hecho mismo noticiable, que representa un mérito intrínsecamente considerado y que va a servir para dignificar a ese menor ${ }^{19}$.

Estos criterios genéricos deben ser ampliados y matizados respecto de los menores de edad. De forma que, en su caso, no serán suficientes para su protección, debiendo atender siempre en primer lugar al principio de no identificación del menor. Y ello porque los datos que permiten la identificación del menor no contribuyen al interés público de la información ni tampoco aportan nada a la formación de la opinión pública. Añadiéndose, además, que la información en todo caso deberá tratarse conforme a criterios éticos de profesionalidad y ser respetuosa con el menor.

En este sentido, es de obligada referencia el artículo 7 de la reciente Ley 7/2010, de 31 de marzo, General de la Comunicación Audiovisual ${ }^{20}$. Uno de sus capítulos trata de forma individualizada las obligaciones de los prestadores de servicios de comunicación audiovisual con relación a los menores y personas con discapacidad que merecen, a juicio del legislador y de las legislaciones europeas, una protección integral, regulándose ampliamente en su artículo 7 los derechos del menor en este ámbito. En lo que nos interesa, por tanto, esta ley establece un nuevo marco de regulación para el sector audiovisual.

${ }^{15}$ Cft. STC de 12 de diciembre de 1986 (RTC 1986/159); STC de 22 de febrero de 1989 (RTC 1989/51).

${ }^{16}$ Así en STC de 2 de diciembre de 1988 (RTC 1988/231); STC de 5 de noviembre de 1990 (RTC 1990/172); STC de 14 de febrero de 1992 (RTC 1992/20).

${ }^{17}$ Así en STC de 18 de enero de 1993 (RTC 1993/15); STS de 21 de enero de 1988 (RTC 1988/6).

${ }^{18}$ Así en STC de 6 de junio de 1990 (RTC 1990/105); STS de 13 de febrero de 1995 (RTC 1995/42); SSTC de 22 de mayo de 1995 (RTC 1995/76 y RTC 1995/78).

${ }^{19}$ Así se pronunció Hernando, P., ex consejero del CGAE y abogado penalista, en la Mesa Legal "Medios e intimidad: perspectiva legal", en el Seminario sobre el "Tratamiento de los menores en los medios de comunicación: propuestas para un cambio", celebradas en Madrid el día 1 de diciembre de 2009 y recogidas posteriormente en Menores en los medios de comunicación: información responsable o espectáculo, Defensor del Menor en la Comunidad de Madrid, Consejo General de la Abogacía Española, Asociación de la Prensa de Madrid Editores, febrero de 2011.

${ }^{20} \mathrm{BOE} \mathrm{N}^{\circ} 79$, de 1 de abril de 2010. 
Así, el apartado primero del artículo 7 establece que "Los menores tienen el derecho a que su imagen y voz no sean utilizadas en los servicios de comunicación audiovisual sin su consentimiento o el de su representante legal, de acuerdo con la normativa vigente. En todo caso, está prohibida la difusión del nombre, la imagen u otros datos que permitan la identificación de los menores en el contexto de hechos delictivos o emisiones que discutan su tutela o filiación”. Y su apartado 2.1 añade: "Está prohibida la emisión en abierto de contenidos audiovisuales que puedan perjudicar seriamente el desarrollo físico, mental o moral de los menores, y en particular, programas que incluyan escenas de pornografía o violencia gratuita. El acceso condicional debe posibilitar el control parental".

Por tanto, la publicación de información relativa a menores de edad en los medios de comunicación deberá atenerse a las siguientes consideraciones ${ }^{21}$. La primera de ellas es que se podrá publicar información relativa a menores que no suponga en modo alguno un perjuicio para estos siempre que exista el consentimiento del propio menor maduro o de sus representantes legales ${ }^{22}$. Y por otra parte, sería posible publicar información respecto de hechos considerados perjudiciales para el interés del menor siempre y cuando la información fuese de interés público y, por supuesto, no se revelase la identidad del menor, tal y como se deduce del artículo 4.3 LO 1/1996. O, dicho de otro modo, se podrá sacrificar la intimidad de un menor a favor de la libertad de información solamente cuando concurran los siguientes requisitos mínimos: que la información que se difunda sea veraz, que tenga un interés público relevante y que no lesione el interés del menor.

Respecto del requisito que exige contar con el consentimiento del menor o de sus representantes legales, tal y como se desprende de la LO 1/1982, debemos aclarar que la relevancia de dicho consentimiento ante intromisiones por los medios de comunicación quedó, tras la LO 1/1996, muy debilitada ${ }^{23}$. El consentimiento del menor o de

${ }^{21}$ Para profundizar más al respecto, De Lama Aymá, A., La protección de los derechos... cit., pp. 272-275.

${ }^{22}$ Vid., al respecto, la STS de 6 de septiembre de 2011 (RJ 2011/6299), en la que se aprecia intromisión ilegítima en los derechos a la intimidad y la propia imagen de una menor que no prestó su consentimiento para que se publicase una fotografía suya en top-less.

${ }^{23} \mathrm{La}$ intensificación en los niveles de protección que introdujo la LO 1/1996, se justifica teniendo en cuenta que la entidad del daño se multiplica exponencialmente cuando el ataque a los derechos del menor se realiza por los medios de comunicación. La alusión a los medios de comunicación como única vía de intromisión es resultado de la obsesión del legislador por proteger al menor en aquellos supuestos en que este se ve involucrado activa o pasivamente en una situación que despierta la curiosidad pública y el sensacionalismo informativo hasta extremos contrarios a sus intereses. Así, De Lama Aymá, A., La protección de los derechos... cit., p. 251. En este sentido, hacen referencia al perjuicio que pueden causar en el menor los medios de comunicación: Varela García, C., "Comentarios a la ley orgánica 1/1996, de 15 de enero, de protección jurídica del menor: principios programáticos y normas de conflicto”, en Actualidad Civil, 1997 1, p. 267; Rivera Fernández, M., “Anotaciones a la Ley 1/1996, de15 de enero, de protección jurídica del menor", en Revista General de Derecho, 1996, No 621, pp. 6505 y ss.; Folguera Crespo, J., "Protección del menor y libertad de información”, en Actualidad Jurídica Aranzadi, 1993, No 127, pp. 2-3. Cabe aclarar, no obstante, que aunque la LO 1/1996 se refiera exclusivamente a los medios de comunicación, esta alusión debería ser interpretada en el sentido más amplio posible. Así, entendemos que la intromisión ilegítima puede perpetrarse, en general, en el ámbito audiovisual; mediante otras vías como la red informática, considerando los riesgos que comportan actualmente las nuevas tecnologías y las redes sociales para los menores de edad, 
sus representantes legales ya no actúa como causa justificativa de la intromisión; es más, resulta absolutamente irrelevante. Por tanto, aunque la regla general establecida en el artículo 3 de la LO 1/1982 es que el menor puede prestar por sí mismo el consentimiento en actos relativos a sus derechos de la personalidad cuando tenga madurez suficiente, ello debe someterse a una regla de protección de los bienes jurídicos de la personalidad; según la cual, la regla general quebrará cuando el acto para el cual se presta el consentimiento por el menor de edad sea contrario a su honor o a sus bienes jurídicos de la personalidad. Así, si la intromisión se da en el ámbito audiovisual e implica un menoscabo en el honor del menor o es contraria a los intereses del mismo, carece de eficacia el consentimiento prestado por el propio menor o sus representantes legales ${ }^{24}$. En definitiva, la LO 1/1996 introduce de forma expresa el interés superior del menor como criterio para determinar la ilegitimidad de la intromisión en el honor, la intimidad y la propia imagen del menor. De este modo, en el ámbito audiovisual se prevé un control a posteriori para que el Ministerio Fiscal intervenga cuando, aun existiendo condiciones de madurez suficientes en el menor o habiéndose prestado el consentimiento por parte

o la telefonía móvil (especialmente desde la aparición en el mercado, y su extendido uso generalizado, de teléfonos móviles con cámaras incorporadas que facilitan la toma no consentida de imágenes).

${ }^{24}$ No podemos dejar de señalar que este precepto ha sido reiteradamente criticado por la doctrina, calificándolo incluso de "perturbador" (Cft. Gullón Ballesteros, A., "Sobre la Ley 1/1996, de Protección Jurídica del Menor”, en @La Ley, D-40, 1996, para quien los preceptos legales más inocuos de la LO 1/1996 no dejan de causar posibles perturbaciones), por considerar que desconoce lo dispuesto en el artículo 3 de la LO 1/1982. Así, mientras el artículo 3.1 de la LO 1/1982 reconoce al menor con suficiente madurez capacidad para legitimar mediante su consentimiento las intromisiones realizadas por terceros en su honor, intimidad o imagen, la LO 1/1996 aparentemente le priva de dicha capacidad. Así lo manifiestan, entre otros, Gullón Ballesteros, A., "Sobre la Ley 1/1996,... cit.; Rivera Fernández, M., "Anotaciones a la Ley 1/1996,...cit.,

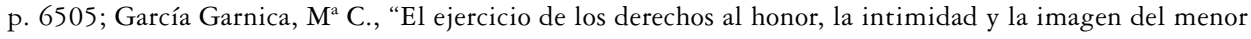
no emancipado", en El ejercicio de los derechos de la personalidad del menor de edad no emancipado, Thomson Aranzadi, Navarra, 2004, pp. 208-214. Por otra parte, parece que la irrelevancia del consentimiento de los representantes legales podría encontrar fundamentación en la propia Exposición de Motivos de la LO 1/1996, donde se señala que "con ello se pretende proteger al menor, que puede ser objeto de manipulación incluso por sus propios representantes legales o grupos en los que se mueve”. No obstante, la ley parece olvidar los requisitos legales que para este fin se establecen en el artículo 3.2 de la LO 1/1982, consistentes en la aprobación tácita o expresa del Ministerio Fiscal. Pues bien, entre otras muchas interpretaciones dadas por la doctrina desde el año 1996, y aceptando que la previsión de la LO 1/1996 no desvirtúa lo dispuesto en el artículo 3 de la LO 1/1982, reseñamos y compartimos la opinión de Santos Morón, Ma J., (Vid. "A propósito de la STS de 26 de marzo de 2003: menores y medios de comunicación. El artículo 4 LO 1/96 de Protección Jurídica del Menor", en Libro Homenaje al Prof. Manuel Albaladejo García, II, Colegio de Registradores, Madrid, 2004, pp. 4665-4666), según la cual la norma se refiere a las lesiones no consentidas en el derecho al honor. En este sentido, el precepto estaría pensado para aquellas hipótesis en que, ya sea el menor, ya sus representantes (con la aprobación del Ministerio Fiscal), consienten que por medio de la utilización de la imagen o el nombre del menor en los medios de comunicación se desvele la identidad de este, pero sin preveer que el contenido de la información o el trato dado a la misma por los medios pueda lesionar el honor del menor identificado. Tesis que comparten, implícita o explícitamente, autores como Gullón Ballesteros, A., "Sobre la Ley 1/1996,... cit.; O’Callaghan Muñoz, X., "Personalidad y derechos de la personalidad (honor, intimidad e imagen) del menor, según la ley de protección del menor”, en @Diario La Ley, 1996; y, más detalladamente la desarrolla García Garnica, Ma C., "El ejercicio de los derechos al honor,...”, cit., pp. 208-214. 
de sus padres o representantes legales, considere que el acto puede ser perjudicial para el superior interés del menor ${ }^{25}$.

Por otra parte, no es menos cierto que encontramos casos en los que el TS ha considerado que hubo un consentimiento del menor eficaz para justificar el acto de intromisión realizado por los medios de comunicación, que a consecuencia de ello dejó de ser ilegítimo. En este sentido, destacamos una sentencia que podríamos calificar de polémica por la repercusión que ocasionó entre la doctrina. Se trata de la STS de 26 de marzo de $2003^{26}$, en la que el TS considera que no hay intromisión ilegítima en el derecho al honor, la intimidad o la imagen de un menor que apareció entrevistado en un programa de televisión explicando una serie de problemas familiares y de agresiones recibidas porque tanto la madre como el menor habían prestado su consentimiento. Así, argumenta que "el contenido de la doble entrevista no alcanza a ser considerada una intromisión ilegítima en el derecho a la intimidad; entender otra cosa significaría dar un sentido amplísimo al concepto de “círculo íntimo"”. Añade que "tanto lo que se dice como la imagen que aparece se hace en presencia y con consentimiento de la madre, representante legal del menor", y que con catorce años que tenía el menor afectado, nada permitía "negar unas claras condiciones de madurez para consentir una entrevista en televisión”; concluyendo la prevalencia del derecho de información, la falta de intromisión ilegítima en la intimidad del menor y el consentimiento en la divulgación de hechos personales y de la aparición de la imagen del menor en televisión. No obstante, la resolución ha sido reiteradamente criticada por la doctrina ${ }^{27}$, por considerar que se debería haber apreciado intromisión ilegítima basadas en el artículo 4.3 LO 1/1996.

Con relación al menor delincuente encontramos preceptos más concretos y adecuados para la protección de este ${ }^{28}$. En primer lugar partimos de la premisa dada por

${ }^{25}$ Teniendo en cuenta que con ello se restringe la capacidad del menor de edad, esta facultad revisora que se concede al Ministerio Fiscal sobre el consentimiento ya prestado por el menor maduro o sus representantes legales debe ser considerada siempre excepcional y aplicada con la máxima cautela. Así, Macías Castillo, A., "El consentimiento del menor y los actos de disposición sobre su derecho a la propia imagen”, en @La Ley, D-94, 2008. Además, la Instrucción 2/2006 señala que deberá valorarse especialmente si pese a tratarse de una intromisión no consentida, el menor maduro o sus representantes legales se oponen motivadamente a que el Fiscal ejercite las acciones en protección de estos derechos. Deberá ser excepcional la intervención autónoma del Fiscal cuando el menor afectado tenga progenitores en pleno uso de las facultades inherentes a la patria potestad, y que -sin que concurra conflicto de intereses con el menor- sean contrarios a que se entablen acciones en defensa del mismo.

${ }^{26}$ RJ 2003/2596. En este caso la demanda, en defensa de la intimidad y la imagen del menor, la interpuso el Ministerio Fiscal en defensa del menor de 14 años, por un programa de televisión en el que se emitía una entrevista al menor hecha en el hospital donde se encontraba tras sufrir una agresión por otros jóvenes. El chico se había ido de casa porque su madre le pegaba y fue llevado a un centro de menores. También se entrevista a la madre, que explicó que su hijo era muy agresivo. Otras sentencias relevantes respecto de la valoración del consentimiento prestado por menores de edad, en las que se pondera la edad de los mismos: SSTS de 12 de julio de 2000 (RJ 2000/6753), de 13 de octubre de 2010 (RJ 2011/1299) y de 25 de febrero de 2009 (RJ 2009/2788).

${ }^{27}$ La critican, entre otros, principalmente Santos Morón, $\mathrm{M}^{\mathrm{a}} \mathrm{J}$., en “A propósito de la STS...”, cit., pp. 4649-4656; y, de manera referencial, De Lama Aymá, A., La protección de los derechos... cit., pp. 131-132 y p. 254.

${ }^{28}$ Para un estudio en profundidad al respecto, Vid. Sáinz-Cantero Caparrós, Ma B. y Pardo Rodríguez, E., Régimen Jurídico de los centros de protección y reforma de menores, Comares, Granada, 2010. 
el artículo 35.2 de la LORPM, según el cual "El Juez podrá acordar, en interés de la persona imputada o de la víctima, que las sesiones no sean públicas y en ningún caso se permitirá que los medios de comunicación social obtengan o difundan imágenes del menor ni datos que permitan su identificación”. Cabe hacer mención también a la Instrucción 2/1993, de 15 de marzo, sobre la función del Ministerio Fiscal y el derecho a la intimidad de los menores víctimas de un delito.

Como vemos, el precepto transcrito prevé el riesgo de estigmatizar al menor por no respetar su derecho a la intimidad. Y es que respecto del tratamiento que los medios de comunicación dan a informaciones referidas a menores delincuentes cabe advertir sobre el riesgo que surge cuando se descontextualiza una información en un medio de comunicación, y se reitera en los demás medios, generándose en los menores una serie de consecuencias a largo y a medio plazo difíciles de ponderar. Así pues, la solución respecto de la publicación de información de interés público relativa a hechos delictivos en los que esté implicado un menor, cuyo interés puede verse claramente perjudicado, pasa nuevamente por la prohibición de difusión de la identidad del menor delincuente.

El fundamento de esta prohibición de identificación del menor delincuente en los medios de comunicación es el propio interés del mismo, como se desprende de la Exposición de Motivos de la LORPM ${ }^{29}$. Está comprobado que existe mayor reinserción en menores que en adultos, por lo que dicha reinserción peligraría por la difusión de la imagen del menor. En efecto, la identificación del menor delincuente en los medios de comunicación perjudica su interés porque dificulta su rehabilitación y reinserción social y, además, porque perjudica el libre desarrollo de su personalidad y vulnera sus derechos fundamentales, especialmente sus derechos al honor y a la intimidad ${ }^{30}$. Además, informar de la identidad del menor delincuente no contribuye en modo alguno a formar la opinión pública.

Por tanto, cuando se trata de informaciones relativas a procesos penales de menores es imprescindible mantener el anonimato del menor, la total ocultación de su imagen, así como la eliminación de cualquier dato que, directa o indirectamente, permita su identificación. Ya que si bien la sociedad tiene derecho a saber determinadas informaciones,

29 Según la cual, textualmente, "han sido criterios orientadores de la redacción de la presente Ley Orgánica, como no podía ser de otra manera, los contenidos en la doctrina del Tribunal Constitucional, (...) sobre las garantías y el respeto a los derechos fundamentales que necesariamente han de imperar en el procedimiento seguido ante los Juzgados de Menores, sin perjuicio de las modulaciones que, respecto del procedimiento ordinario, permiten tener en cuenta la naturaleza y finalidad de aquel tipo de proceso, encaminado a la adopción de unas medidas que, como ya se ha dicho, fundamentalmente no pueden ser represivas, sino preventivo-especiales, orientadas hacia la efectiva reinserción y el superior interés del menor, valorados con criterios que han de buscarse primordialmente en el ámbito de las ciencias no jurídicas”.

${ }^{30}$ En este sentido, De Lama Aymá, A., La protección de los derechos... cit., pp. 270-271, añade que en realidad la prohibición de difundir la identidad del menor delincuente en los medios de comunicación se debe a que la falta de desarrollo intelectual y emocional del menor le impide asumir con cierta normalidad la fuerte repercusión mediática que suelen tener estos casos, de tal manera que se verá afectado en mayor grado que un adulto por el rechazo social que la información provoca hacia él, lo que impedirá el correcto desarrollo de su personalidad. 
estas nunca deben afectar a la intimidad de ese menor, sea víctima, autor o cómplice del delito ${ }^{31}$.

Por otra parte, hay una serie de principios fundamentales que debe tener en cuenta un juez, en todo caso, cuando se enfrenta a un caso en el que están implicados menores: el respeto a la presunción de inocencia, el respeto a la libertad de expresión, el respeto a la libertad de información y, por último, la especial protección a la infancia y el principio del interés superior del menor ${ }^{32}$.

Además, una característica especial de este tipo de casos es que suele primar el interés informativo y la audiencia de los medios de comunicación frente al interés del menor que está siendo enjuiciado. Y ello por una serie de causas, entre las cuales destaca el hecho de que en los medios existe una tendencia a remarcar los detalles más escabrosos de los crímenes (cosa que no sucede en los crímenes cometidos por adultos), haciéndose preguntas tales como: qué entorno familiar tiene el menor delincuente o qué problemas tiene dicho menor para haber llegado a cometer un crimen semejante. Y además, es característico igualmente el seguimiento en el tiempo que se da a este tipo de noticias, desde la comisión del delito, pasando por el enjuiciamiento, la posterior estancia en el centro penitenciario e, incluso, la salida de dicho centro.

En definitiva, si a estas características que se observan en los casos en que se enjuician menores les sumamos que los medios de comunicación priman la audiencia al interés del menor y, además, que en muchas ocasiones el comportamiento de los padres y familiares de estos menores que intervienen en el procedimiento contribuye a empeorar la situación, podemos concluir que el tratamiento informativo es ajeno a la normativa y a los principios de protección del menor ${ }^{33}$.

${ }^{31}$ Así lo expresó Consuelo Madrigal, fiscal de sala coordinadora de menores del Tribunal Supremo, en el Seminario sobre el "Tratamiento de los menores en los medios de comunicación: propuestas para un cambio", celebradas en Madrid el día 1 de diciembre de 2009 y recogidas posteriormente en Menores en los medios de comunicación: información responsable o espectáculo, Defensor del Menor en la Comunidad de Madrid, Consejo General de la Abogacía Española, Asociación de la Prensa de Madrid Editores, febrero de 2011. Algunas resoluciones relevantes que aprecian intromisión ilegítima en los derechos al honor, intimidad y propia imagen por aportar datos que identifican a menores como sujetos pasivos de delitos: SSTS de 23 de octubre de 2008 (RJ 2008/5791), de 14 de mayo de 2009 (RJ 2009/3175), de 9 de julio de 2009 (RJ 2009/4461).

32 Afirmación realizada por Vián Ibáñez, A., Juez de menores del Juzgado $\mathrm{N}^{\circ} 1$ de Sevilla, en la conferencia "Experiencias prácticas en los juicios de menores sobre protección del menor ante los medios de comunicación", pronunciada en el marco de las Jornadas sobre Protección del menor en el ámbito audiovisual, celebradas en la Universidad de Almería los días 12 y 24 de mayo de 2011.

${ }^{33}$ Además, el tratamiento del tema por parte de los medios de comunicación puede provocar consecuencias muy graves. En España todavía no ha pasado, pero en EE.UU. ya se han dado casos de imitación de conductas delictivas por otros menores de edad (por ejemplo, masacres en centros escolares) debido al afán de notoriedad de sus protagonistas. Así lo expresó Vián Ibáñez, A. en "Experiencias prácticas de la protección... cit. Por otra parte, Arturo Canalda, Defensor del Menor de la Comunidad de Madrid, afirmó que existe un acuerdo entre los medios de comunicación respecto de que no se deben ofrecer informaciones relacionadas con suicidios de menores, por el posible efecto dominó. Sin embargo, no ocurre lo mismo con los delitos de los menores, cuando en realidad también en este caso existe un efecto de contagio. No se trataría de no informar, pero sí de tener en cuenta que hay situaciones susceptibles de ser imitadas por otros menores. Declaraciones emitidas en las Jornadas sobre Protección del menor...cit. 
En este sentido, una STS de 28 de junio de $2004^{34}$ relativa a la divulgación en un medio periodístico de un reportaje sobre un menor condenado posteriormente por el asesinato de su hermanastra a causa de los celos, aprecia "violación del derecho al honor y a la intimidad del menor porque se le identificaba con su nombre y apellidos con relación a unos hechos de especial gravedad a pesar de tener solo catorce años. Y si bien ello ocurrió con anterioridad a la publicación de la LO 1/1996, sin embargo considera que se extralimita la libertad de información por las singulares circunstancias del caso y del sujeto". Además, señala que "resulta incuestionable la exigencia de proteger a los menores de edad en casos como el presente en el que un propósito sensacionalista determina un tratamiento desmedido de una desgracia familiar de tanta gravedad como la de autos, tanto más que la relevancia pública del asunto es más bien relativa, y que la libertad de información se corresponde con la finalidad de contribuir a la formación de una opinión pública de interés general. La mención repetida de los datos de identidad del menor, unido a su calificación como chico desobediente y conflictivo y la referencia a haber matado a su hermanastra, constituye una evidente desmesura informativa, resultando absolutamente innecesaria la identificación, como también ocurre con la inclusión de una fotografía del mismo que figura en el reportaje aunque se le hayan tapado los ojos con una franja blanca. Tal forma de publicación es totalmente negativa para la integridad moral y formación de los menores, contraviniendo la exigencia constitucional de protección de la juventud y la infancia (art. 20.4) y perjudicial para la readaptación social".

En conclusión, cuando los hechos en los que se vea inmerso el menor sean asuntos públicos de interés estará justificada la difusión de la noticia, pero con la adopción de las cautelas que en cada caso dicten las circunstancias para evitar que el mismo se vea perjudicado a causa de su identificación (no incluir el nombre ni la imagen, o distorsionar su rostro de modo que sea imposible su identificación, no aportar datos periféricos que puedan identificarlo, etc.).

A mayor abundamiento, la Instrucción 2/2006 sobre el Fiscal y la protección del derecho al honor, intimidad y propia imagen de los menores prevé que los Fiscales deberán ser especialmente rigurosos en cuanto a la preservación de la identidad de la víctima cuando además de ser esta menor de edad, los hechos investigados, enjuiciados o sentenciados se refieran a delitos contra la libertad sexual. En estos supuestos habrán de considerarse antijurídicos no solo la identificación por nombre y apellidos de las víctimas menores y la captación de su imagen sino también la información sobre datos colaterales al menor que sean aptos para facilitar su identificación.

En este sentido, reseñamos un caso en el que la Fiscalía de Valencia interpuso demanda en defensa del derecho al honor, a la intimidad y a la propia imagen de unos menores ${ }^{35}$. El Ministerio Fiscal, en nombre de seis hermanos menores de edad, cinco de ellos declarados en situación legal de desamparo, formuló demanda contra su progenitora, contra la entidad Cuarzo Producciones SL y contra Antena 3 de Televisión SA. Alegaba

\footnotetext{
${ }^{34}$ RJ 2004/4279.

${ }^{35}$ Vid. SAP Valencia de 1 de marzo de 2003 (AC 2003/1305).
} 
que el día 30 de abril de 2001, en el programa "Sabor a ti" que emite dicha cadena, fue entrevistada la demandada y antes de iniciarse la misma, una voz "en off”, anunciaba que por culpa de un rumor la vida de la citada señora había sufrido un giro de $360^{\circ}$, pues había sido inesperadamente acusada de abusos sexuales y malos tratos a uno de sus hijos. Durante la entrevista, la señora ofreció datos relativos a su localidad de residencia, empleo de su esposo, saliendo un rótulo sobreimpresionado indicando que "me acusan de abusar de mi hijo de ocho años" y mostrándose en dos ocasiones, durante varios segundos y en un primer plano que abarcaba toda la pantalla, la fotografía de todos los miembros de la familia, siendo fácilmente identificable el menor de ocho años al que se hacía referencia.

El Fiscal alega que la reiterada exhibición de la fotografía en la que aparecen los hermanos en el programa de televisión así como el modo en que esa exhibición se produce, supone una intromisión ilegítima que vulnera el derecho al honor, la intimidad y la propia imagen de todos los menores, pues cualquier espectador del programa, entre los que se encontraban familiares, vecinos, amigos y compañeros de colegio de los menores, puede identificar plenamente a los niños. Además, las propias manifestaciones de su progenitora relativas a las circunstancias familiares, sociales, educativas y económicas en que se ha desenvuelto la vida de sus hijos, son contrarias a los intereses de los menores, puesto que tienen derecho a que nadie se introduzca en su vida familiar y a que no se divulguen datos que afecten a su privacidad. Pero especialmente intensa ha sido la intromisión en el caso del menor de ocho años, pues ha tenido que soportar además la difusión mediante un medio de comunicación de masas de la noticia de que su propia madre abusa sexualmente de él y que esas sospechas han llegado al punto de apertura de un procedimiento judicial por ello.

En la sentencia se estima acreditado que el contenido de la entrevista no era útil para formar una opinión pública informada y en nada ha beneficiado a los menores, ya que solo les ha reportado graves perjuicios, debido a que tras su emisión un gran número de personas ha conocido los desgraciados motivos por los que los menores se hallaban internados en un centro dependiente de la Generalitat, y privados de la visita de sus padres. Y concluye señalando que cuando nos hallamos ante un conflicto entre la libertad de expresión y el derecho a la intimidad de los menores, la ponderación entre ambos derechos no debe ser la misma que cuando la protección se refiere a personas adultas, pues la libertad de expresión en estos casos, como apunta la doctrina, y se desprende del artículo 20 de la Constitución española, ha de quedar muy relativizado.

\section{Un supuesto concreto: Caso “El cuco”- Marta del Castillo}

El deseo de llegar a conocer los detalles más minuciosos que rodearon la comisión del delito, y el afán por captar los aspectos más recónditos de la dinámica delictiva, constituyen un estímulo para que algunos medios de comunicación, en la legítima lucha por afianzar y extender sus respectivas ofertas informativas en tan competitivo mercado, se esfuercen en proporcionar una imagen más que precisa del evento delictivo y de sus protagonistas. 
Pero, sobre todo, la apasionada curiosidad colectiva respecto de aquellos ilícitos que tienen por protagonistas activos o pasivos a menores de edad lleva, en ocasiones, a una indiscreta y multitudinaria injerencia en la investigación judicial. Para lograr absorber esa demanda informativa, determinados medios de comunicación se han esforzado en obtener imágenes y declaraciones de los sujetos del episodio ilícito, proporcionando testimonios documentados que alientan y multiplican el seguimiento colectivo del hecho ilícito.

Así, en no pocas ocasiones hemos sido testigos de los graves perjuicios que se causan a menores de edad como consecuencia de la revelación pública de hechos o circunstancias que atañen a su más estricta intimidad, mediante la difusión de su imagen o de datos de su vida privada. Esto, a menudo, se hace por encima incluso de la función social informadora que tienen los medios de comunicación y la objetividad y veracidad que se les presupone ${ }^{36}$.

La Instrucción 2/1993, de 15 de marzo, sobre la función del Ministerio Fiscal y el derecho a la intimidad de los menores víctimas de un delito ya advertía que la actuación del Fiscal no puede limitarse a la impasible contemplación de maquinaciones familiares que, orientadas hacia el tan fácil como inesperado rendimiento económico, puedan perjudicar gravemente el proceso de socialización del menor y, con ello, su desarrollo integral. Conviene recordar que ya el artículo 154.1 del Código Civil, cuando se ocupa de fijar el contenido de la patria potestad, alude a la obligación de los padres, respecto de sus hijos, de "educarlos y procurarles una formación integral”. De ahí que un continuo y pertinaz incumplimiento de las obligaciones inherentes a la patria potestad o una reiterada estrategia de exposición pública del menor para el relato de su propia tragedia, pueden llevar a emerger la categoría jurídica del desamparo con la consiguiente guarda por parte de la entidad pública a la que, en el respectivo territorio, esté encomendada la protección de menores. Resulta aceptable, aunque no sin dificultades detectables, que tal concepto legal del desamparo puede acoger en su ámbito la inadmisible actuación del grupo familiar que antepone el rendimiento económico derivado del drama vivido por el menor a la ineludible y tan necesaria intimidad que la propia naturaleza de las cosas aconseja.

En definitiva, la perplejidad social que produce la impune utilización del infortunio infantil, exige una activa y decidida respuesta de los fiscales a fin de impedir que la desdicha que ha convertido al menor en víctima de un hecho delictivo lleve aparejada, como ineludible añadido, el frecuente recuerdo de los pormenores de la ofensa padecida.

En este sentido, hay que advertir del peligro de los juicios paralelos que alteran el procedimiento judicial. En ocasiones, una vez archivado el caso por vía judicial, son las propias familias las que, no contentas con la decisión, acuden a la prensa y van de televisión en televisión "explicando" la historia, de manera que se llega a juzgar a

${ }^{36}$ Así lo expresó Arturo Canalda, Defensor del Menor de la Comunidad de Madrid, en el Seminario sobre el "Tratamiento de los menores en los medios de comunicación: propuestas para un cambio", celebradas en Madrid el día 1 de diciembre de 2009 y recogidas posteriormente en Menores en los medios de comunicación: información responsable o espectáculo, Defensor del Menor en la Comunidad de Madrid, Consejo General de la Abogacía Española, Asociación de la Prensa de Madrid Editores, febrero de 2011. 
personas que no tienen nada que ver y que se ven acosadas por la sociedad vulnerando el principio de presunción de inocencia.

En otros casos, la polémica social surge cuando el juez finalmente no condena y declara inocente a quien fue "imputado" paralelamente por el juicio público. Al respecto, Vián Ibáñez, Juez de menores del Juzgado $\mathrm{N}^{\circ} 1$ de Sevilla, relató brevemente su experiencia práctica en el conocido como caso "Cuco"37.

Según el juez, el primer problema con el que se enfrentó fue elegir el sitio físico donde celebrar el juicio, ya que el lugar debía englobar la protección del interés del menor y la protección igualmente del derecho de información de los medios de comunicación.

Una vez más, nos hacemos eco del contenido del artículo 35.2 de la LORPM, para recordar que "El juez podrá acordar, en interés de la persona imputada o de la víctima, que las sesiones no sean públicas y en ningún caso se permitirá que los medios de comunicación social obtengan o difundan imágenes del menor ni datos que permitan su identificación”. Así pues, el juicio se grabó y se distribuyeron copias entre el Fiscal, la Acusación Particular y el juez. Las sesiones se celebraron a puerta cerrada, sin público y solamente se permitió el acceso a dos miembros de la familia de Marta del Castillo. A parte de esto, solo se pudo acceder a la sala para hacer fotografías dos o tres días antes del juicio.

Pues bien, se intentó dar a los medios de comunicación una información mínima durante los 3 primeros días, por parte del gabinete de prensa y supervisada por el propio juez. Pero los medios rechazaron la información que se les ofrecía y optaron por hablar con el Ministerio Fiscal, la Acusación Particular y, además, con los padres de Marta del Castillo. El problema que ello conllevó fue el desarrollo de un juicio paralelo en la calle, provocándose una expectativa que posteriormente no se ha cumplido. El resultado, tras la resolución del juez Vián Ibáñez ${ }^{38}$, que absolvió al Cuco de la violación y el asesinato de la joven Marta del Castillo por inexistencia de pruebas, los titulares en los medios de comunicación rezaban: "La Ley del Menor no es válida" o "Los jueces están comprados".

Por otra parte, este caso ha dado lugar a la interposición de acciones frente a intromisiones en el derecho a la propia imagen de los menores relacionados con la muerte de la joven Marta del Castillo. Así pues, la Fiscalía de Sevilla ha interpuesto una demanda contra una cadena de televisión, como consecuencia de la utilización en tres programas

${ }^{37}$ El "Cuco" es un menor de edad implicado en el asesinato, el 24 de enero de 2009, de la joven Marta del Castillo. Caso que tiene desde entonces conmocionada a la opinión pública, ya que su cadáver nunca se halló, pese a su insistente búsqueda por parte de los cuerpos de seguridad del Estado. El menor fue absuelto del asesinato y la violación de Marta del Castillo y condenado sólo por encubrir el crimen.

38 Vid. Sentencia de 24 de marzo de 2011 (ARP 2011/287). Esta sentencia fue recurrida ante la Audiencia de Sevilla (Vid. Sentencia de 20 de octubre de 2011, JUR 2011/362817), que confirmó la resolución del juez Vián Ibáñez, absolviendo al Cuco del asesinato y la violación de Marta del Castillo y condenado sólo por encubrimiento. Lo único en lo que la Sección Tercera de la Audiencia de Sevilla corrige al Juez de Menores es en la imposición a los padres del menor del pago de una indemnización para pagar parte de los operativos montados para buscar el cuerpo de Marta, que en la primera sentencia no se establecía. Respecto de la responsabilidad civil de los padres por los daños causados por sus hijos, Vid. Paños Pérez, A., La responsabilidad civil de los padres por los daños causados por menores e incapacitados, Atelier, Barcelona, 2010. 
de la imagen de dos menores, uno de ellos, la novia del presunto asesino de Marta. Las investigaciones abarcarán también la imagen que se ofreció de la propia Marta y la de su círculo de amistades e incluso la del menor "El Cuco", debido a la publicación en diversos medios de comunicación de imágenes de todos ellos sacadas de redes sociales como Tuenti. Según la Fiscal Jefe de Sevilla, María José Segarra, tanto las imágenes de los menores como las declaraciones mencionadas "les pueden causar un daño irreparable". $Y$ es que, poco después de la noticia del asesinato que conmocionó a la opinión pública, la novia del presunto asesino, una menor de 14 años de edad, aparecía en diversos programas de televisión, acompañada por su madre, haciendo declaraciones respecto del caso. La demanda de la Fiscalía de Sevilla se fundamenta en el argumento de que los mencionados reportajes vulneraron el derecho a la intimidad y a la imagen de los menores implicados ${ }^{39}$.

Lo irónico del caso estriba en que la menor de edad a quien se pretende proteger, que podríamos considerar indudablemente como menor madura teniendo en cuenta su edad de 14 años y sus circunstancias vitales, no solo consintió voluntariamente la captación de su imagen, sino que se especula con la posibilidad que la madre de la menor, cuyo consentimiento otorgó tácitamente al acompañar a su hija en dichas apariciones televisivas, cobrara 6.000 euros por la entrevista. Se plantea entonces una incómoda paradoja, debido a que la Fiscalía solicita una cuantiosa indemnización a favor de la menor por intromisiones en su derecho a la imagen ${ }^{40}$ : ¿no se les estará premiando económicamente por una intervención morbosa de la que resulta un perjuicio objetivo para esta, al verse mezclada en unos hechos de relevancia penal y de gran trascendencia social? ${ }^{41}$ Algo que, sin duda, se podría haber evitado mediante la utilización de técnicas de distorsión de la imagen, lo que hubiera impedido su identificación.

Por otra parte, tampoco podemos olvidar que a la hora de denunciar un caso de estas características, es imprescindible que el Fiscal valore detenidamente si el daño que se puede causar al menor con la actuación va a resultar mayor que el que ya se le ha ocasionado. No cabe duda que la denuncia puede provocar en muchas ocasiones un efecto contraproducente al conllevar una vuelta a la atención sobre el caso.

39 Vid. SJPI de 11 de enero de 2011 (AC 2011/82).

${ }^{40}$ En principio, la fiscalía reclamaba 100.000 euros. Sin embargo, el juez considera que, pese a que existiera el consentimiento de la menor madura, que justificaría la revelación pública de su imagen y de detalles de su vida personal, objetivamente se aprecia un menoscabo en su reputación y un perjuicio a sus intereses, por lo que finalmente se estima la intromisión ilegítima en los derechos fundamentales a la intimidad y la propia imagen de la menor. No obstante, ponderando las circunstancias del caso, se rebajó la indemnización a la suma de 6.000 euros, fundamentándose en que una cantidad mayor vendría a propiciar un fin distinto al perseguido por el proceso, es decir, que so pretexto de limpiar la imagen enturbiada de la menor se le haría pasar públicamente como una persona que se lucra de la muerte ajena. Vid. SJPI de 11 de enero de 2011 (AC 2011/82), en su Fundamento de Derecho Sexto.

${ }^{41}$ Vid. De Veda y Beamonte, J. R., "Resarcimiento del daño moral por intromisiones consentidas en el derecho a la propia imagen de menores (en relación al caso Marta del Castillo)”, en Diario La Ley, N ${ }^{\circ} 7171$, Ref. D-167, mayo de 2009. 


\section{COnClusiones}

La Instrucción 2/2006, entendiendo que esta es una materia casuística por definición en la que cada caso concreto deberá resolverse mediante la técnica de la ponderación, recoge unos criterios generales que nos parece de interés reseñar a efectos de recapitulación.

En primer lugar, la difusión de la imagen de un menor en un medio de comunicación exige contar con el consentimiento del propio menor maduro o de sus representantes legales. No obstante, aun contando con los preceptivos consentimientos, si la difusión de la identidad o de la imagen del menor puede considerarse contraria a sus intereses, la intromisión en principio será ilegítima.

De otra parte, no procederá en general el ejercicio de acciones por el Ministerio Fiscal ante la emisión de programas o la publicación de fotografías en los que aparezcan menores, en actividades con dimensión pública tales como concursos, debates, musicales, actividades deportivas, etc., siempre que las propias circunstancias que rodeen la publicación excluyan el perjuicio para los intereses de los mismos. Tampoco procederá en general el ejercicio de acciones por el Ministerio Fiscal ante la difusión de imágenes de menores en lugares públicos, cuando aparezcan de manera meramente casual o accesoria de la información principal y siempre que tales lugares o actos no presenten aspectos negativos. Y, por último, si la difusión casual o accesoria de la imagen del menor se vincula a lugares, personas o actos con connotaciones negativas, habrán de utilizarse técnicas de distorsión de la imagen para evitar que el mismo pueda ser identificado.

En puridad, la Instrucción recomienda prudencia a los fiscales a la hora de intervenir en defensa de los derechos de los menores y, para actuar con responsabilidad, ofrece una serie de criterios entre los que destacaríamos el riesgo del estrepitas. forte, es decir, que la intervención del Fiscal o la repercusión mediática de una demanda puedan suponer una mayor incidencia nociva y contraria a los intereses del menor que la propia intromisión inicial en su intimidad, honor o imagen.

Concluimos que los derechos al honor, a la intimidad y a la propia imagen del menor no son absolutos. Cuando entran en colisión con las libertades de información y expresión habrá que ponderar cuál merece mayor protección y cuándo estará justificado limitar uno u otro. En todo caso, debe tenerse en cuenta que para sacrificar la intimidad de un menor a favor de la libertad de información deben concurrir unos requisitos mínimos, a saber: que la información sea veraz, de interés público y que no lesione los intereses del menor. Así, las informaciones que versen sobre un menor, que solo podrán publicarse en atención a dichos requisitos, deberán resguardar siempre su identidad, defendiendo su total anonimato y la total exclusión de su imagen mediante mecanismos de desaparición de la misma, sin ofrecer, en ningún caso, datos que permitan su identificación. No cabe duda que el superior interés del menor será, a la hora de ponderar los diferentes intereses en conflicto, el de mayor peso, tal y como dicta el artículo 2 LO 1/1996.

Sin embargo, no podemos olvidar que cuando el Fiscal interviene ya se ha producido la intromisión y el daño al menor, por eso es importantísima la labor preventiva. Para ello, en primer lugar hay que hacer cumplir la LO 1/1982 que otorga validez al consentimiento prestado por el menor maduro o, en su defecto, por sus representantes 
legales, quienes están obligados a poner en conocimiento previo del Ministerio Fiscal el consentimiento proyectado. El problema es que en la práctica esta garantía previa para los menores prevista en la ley mediante la vigilancia del Fiscal no se produce porque habitualmente los padres no comunican previamente al Fiscal el consentimiento que tienen previsto otorgar, bien porque desconocen esta obligación, bien porque no desean que el Fiscal se oponga y pueda impedirlo. Pero tampoco son informados por el medio de comunicación en cuestión, lo que de producirse facilitaría la intervención previa del Ministerio Fiscal que, en caso de estimar que debe actuar, podría hacerlo antes de que se cause un daño ${ }^{42}$. Por ello y en segundo lugar, es imprescindible la implicación de los medios de comunicación, debe exigírseles una mayor intervención activa en defensa de los derechos del menor.

Así, finalmente, reiteramos la necesidad de reflexionar sobre el actual marco jurídico para la protección de los menores que, si bien es indudablemente amplio, resulta ser insuficiente a nivel práctico o, cuanto menos, poco eficaz en el ámbito de los medios de comunicación. Frente a una autorregulación periodística que se ha demostrado ineficaz en España (si no prácticamente inexistente), consideramos necesario establecer un régimen sancionador adecuado, disuasorio y proporcionado frente a actuaciones inadecuadas de los medios de comunicación en perjuicio de los menores.

A tal efecto, reclamamos a los poderes públicos competentes que se haga efectiva la propuesta hecha por la reciente Ley 7/2010, de 31 de marzo, General de la Comunicación Audiovisual, de creación de un Consejo Estatal de Medios Audiovisuales, como órgano independiente regulador y supervisor del sector y con potestad para sancionar a los medios infractores, imponiendo multas económicas ${ }^{43}$. No obstante, cabría plantearse si las sanciones previstas por dicha ley son realmente rentables para los medios de comunicación sancionados. No cabe duda que, siendo las sanciones relevantes, la sanción "social" resulta en cualquier caso más efectiva ${ }^{44}$. En puridad, esta nos parece la única vía para impedir que el tráfico informativo con los menores continúe saliendo gratis.

\footnotetext{
${ }^{42}$ Gisbert Jorda, T. "El fiscal y la protección del menor", en el Seminario Menores y medios de comunicación, celebrado en Murcia los días 22, 23 y 24 de junio de 2009.

43 Existen Consejos Audiovisuales en varias Comunidades Autónomas (actualmente solo en dos, Andalucía y Cataluña, puesto que el de Navarra fue suprimido en 2011 por recortes presupuestarios) que son órganos con potestad de control a posteriori (que no de censura) y sancionadora, con competencia estrictamente audiovisual (sobre televisión y radio, excluyendo prensa escrita e internet). Sin embargo, los medios audiovisuales estatales no están controlados. Así, la UE lleva veinte años reclamando a España la creación de un órgano estatal de control audiovisual, teniendo en cuenta que el resto de países de la Unión tiene ya un órgano de este tipo. Pues bien, la creación de este Consejo Estatal de Medios Audiovisuales fue retrasada por el anterior Gobierno hasta la siguiente legislatura. Y el pasado mes de febrero de 2012, el Gobierno actual anunció que finalmente la creación del Consejo Estatal de Medios Audiovisuales se hará efectiva mediante su incorporación como organismo "supervisor", más que "regulador", a la Comisión Nacional de Mercados y Competencia, que centralizará las tareas actuales de distintos organismos supervisores. Así pues, tendremos que esperar aún unos meses para dilucidar si la tarea que desempeñe dicho órgano cumple nuestras expectativas de manera eficaz.

${ }^{44}$ Inevitablemente nos viene a la mente el reciente caso del malogrado programa "La Noria", con relación al "Caso Cuco". El pasado 29 de octubre de 2011 dicho programa entrevistaba a la madre del "Cuco",
} 


\section{BIBLIOGRAFÍA}

Alonso Pérez, M., "La situación jurídica del menor en la Ley Orgánica 1/1996, de 15 de enero, de protección jurídica del menor, de modificación del Código Civil y de la Ley de Enjuiciamiento Civil: luces y sombras", en Actualidad Civil, No 2, 1997.

Camps Mirabet, N., "El principio del interés superior del menor: marco normativo internacional y aplicación en el derecho interno", en Estudios jurídicos sobre la protección de la infancia y de la adolescencia, Tirant lo Blanch, Valencia, 2007.

CAnalda, A., Menores en los medios de comunicación: información responsable o espectáculo, Defensor del Menor en la Comunidad de Madrid, Consejo General de la Abogacía Española, Asociación de la Prensa de Madrid Editores, 2011.

De Lama Aymá, A., La protección de los derechos de la personalidad del menor de edad, Tirant lo Blanch, Valencia, 2006.

De Veda y Beamonte, J. R., "Resarcimiento del daño moral por intromisiones consentidas en el derecho a la propia imagen de menores (en relación al caso Marta del Castillo)", en Diario La Ley, $\mathrm{N}^{\circ}$ 7171, Ref. D-167, 2009.

Folguera Crespo, J., "Protección del menor y libertad de información”, en Actualidad Jurídica Aranzadi, 1993, N 127.

García GARniCA, M ${ }^{a}$ C., "El ejercicio de los derechos al honor, la intimidad y la imagen del menor no emancipado", en El ejercicio de los derechos de la personalidad del menor de edad no emancipado, Thomson Aranzadi, Navarra, 2004.

Gullón Ballesteros, A., "Sobre la Ley 1/1996, de Protección Jurídica del Menor", en @La Ley, Ref. D-40, 1996.

JimÉnEZ-Aybar, I., "Diálogo sobre el principio del interés superior del menor", en La familia, protagonista, Comisión Organizadora del Congreso General de Familia, 2003.

Linacero de la Fuente, M., "La protección del menor en el Derecho civil español. Comentario a la Ley 1/1996, de 15 de enero", en Actualidad Civil, La Ley, 1999.

Macías Castillo, A., "El consentimiento del menor y los actos de disposición sobre su derecho a la propia imagen", en@La Ley, Ref. D-94, 2008.

Navas Navarro, S., "El bienestar y el interés del menor desde una perspectiva comparada", en Estudios Jurídicos en Homenaje al Profesor Luis Díez-Picazo, T. I, Madrid, 2003.

O’Callaghan Muñoz, X., "Personalidad y derechos de la personalidad (honor, intimidad e imagen) del menor, según la Ley de protección del menor”, en @Diario La Ley, 1996.

Paños PÉrez, A., La responsabilidad civil de los padres por los daños causados por menores e incapacitados, Atelier, Barcelona, 2010.

Rivera Fernández, M., “Anotaciones a la Ley 1/1996, de15 de enero, de protección jurídica del menor", en Revista General de Derecho, 1996, № 621.

Rivero Hernández, El interés del menor, $2^{\mathrm{a}}$ ed., Dykinson, Madrid, 2007.

previo pago de unos 10.000 euros, según informaciones periodísticas (lo que provocó que la Fiscalía de Sevilla solicitase la intervención de dicha cantidad de dinero, dada la indemnización de 414.000 euros fijada por la Audiencia Provincial por los gastos de la búsqueda del cuerpo de Marta del Castillo, que los padres del "Cuco" no pagaron por declararse insolventes), apenas unos días después de la sentencia exculpatoria de su hijo. Tras dicha aparición televisiva, se desató un aluvión de críticas mediante las redes sociales, lo que motivó una huida sin precedentes de los anunciantes que sostenían el formato del programa, provocando la retirada definitiva del mismo pocos días después. 
Sáinz-Cantero Caparrós, Mª B. y Pardo Rodríguez, E., Régimen Jurídico de los centros de protección y reforma de menores, Comares, Granada, 2010.

Santos Morón, M Ma J., "A propósito de la STS de 26 de marzo de 2003: menores y medios de comunicación. El artículo 4 LO 1/96 de Protección Jurídica del Menor”, en Libro Homenaje al Prof. Manuel Albaladejo García, II, Colegio de Registradores, Madrid, 2004.

VArela García, C., "Comentarios a la ley orgánica 1/1996, de 15 de enero, de protección jurídica del menor: principios programáticos y normas de conflicto”, en Actualidad Civil, 1997-1. 